\title{
Production and Marketing of Coffee Crops with Special Reference to Coffee Plantations in Dindigul District
}

\author{
M. Anbarasi, S. Praveen Kumar
}

\begin{abstract}
Marketing consists of the performance of business activities that direct the flow of goods and services from the producer or supplier to the consumers or end-users. Marketing is a total system of business activities designed to plan, price, promote and distribute want-satisfying goods and services to present and potential customers. According to Stanton, "Marketing mix is the term used to describe the combination of the four inputs which constitute the core of a company's marketing system the product, the price structure, the promotional activities and the distribution system. A brief description of the four elements of marketing mix is product, Price, Promotion, and Distribution. The product itself is the first element. Products must satisfy consumer needs. The management must, first decide the products to be produced, by knowing the needs of the consumers. The product mix combines the physical product, product services, brand and packages. The marketing authority has to decide the quality, type of goods or services which are offered for sale. A firm may offer a single product (manufacture) or several products (seller).
\end{abstract}

Keywords: Marketing, Consumer, End User

\section{INTRODUCTION}

Physical distribution is used, generally to describe a series of interrelated activities[1],[3],[5]. The term is generally used to describe a series of interrelated activities concerned with transporting finished goods and raw materials so that they arrive at the designated place when needed and in usable condition. According to Philip Kolter, "physical distribution involves planning, implementing and controlling the physical flow of materials and final goods from points of origin to points of use to meet customer needs at a point," In between the producer and the user, there exist certain "gaps" on account of the reasons[2 ],[4],[6]. Production is concentrated whereas customers are scattered widely. Production is continuous but consumption is infrequent. Production is on a large scale but consumers buy in a small quantities. Knowledge gap between producers and consumers. Physical distribution management may be divided into the following broad areas of managerial responsibility. Physical distribution management consisting of transportation and storage.Logistical coordination and material management. The first aspect is concerned with arranging a proper mode of transportation and arranging of

Revised Manuscript Received on July 22, 2019.

M. Anbarasi, Department of MBA, Bharath Institute of Higher Education and Research, Chennai, India.

Email: praveenkumar.mba@bharathuniv.ac.in

Dr. S. Praveen Kumar Department of MBA, Bharath Institute of Higher

Education and Research, Chennai, India.

Email: praveenkumar.mba@bharathuniv.ac.in store locations (warehouse) at convenient places. Logistical coordination is a critical element of effective physical distribution management. It is a process that harmoniously combines physical distribution and materials management[7],[9],[11]

Holtz claw vividly puts the importance of transportation in the following lines:" Minerals or other raw materials are to be transported from the place of extraction or production to the factory; crops are to be carried from the farm to the local market or primary market and from the places of consumption[8],[10],[12]. Finished products are to be transported from the warehouse to the wholesale warehouse, from warehouse to the retail dealer, and from the dealer to the ultimate consumer." It is said that if agriculture and industry are the body and bones of a national organism, transport and communication are its nerves. Transport performs a large number of functions.

Like transportation, storing is also a major arena for marketing management decisions. Proper storing contributes a real asset to the product; It provides time utility to the product. Production becomes meaningful only if the products reach the point of consumption in time. If transportation is the process of transferring goods from one place to another, Storage is a function which helps in preserving the goods at one place until they are needed at another place. Both these functions are complementary and entwined and it is difficult to separate them[13], [15],[17]. Without, transportation is impossible and storing is made possible by transportation. This is why both these functions are grouped under physical distribution. By preserving goods from the time of production to the time of consumption, storage helps in the steady flow of goods to the market. In this sense, storage is really regarded as the function of equalization. If transporting and advertising are designed to widen the market, then storage must be taken for deepening the market[14],[16], [18].

\section{OBJECTIVES}

Keeping in view the importance of coffee in the state economy the present study makes an attempt to analyse the production and marketing of coffee in Dindigul District, Tamil nadu[19],[21],[23]

The specific objectives of the study are:

i. To estimate the growth in area, production and productivity of coffee in the study area.

ii. To estimate costs and returns in coffee production.

iii. To analyse the role of traders in coffee marketing.

iv. To identify the constraints in production and marketing and to suggest corrective measures.

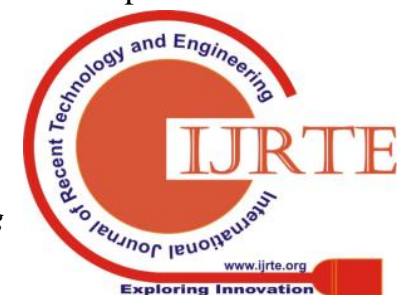




\section{RESEARCH DESIGN}

Research design is the blue print or plan consisting of the procedure of various steps in research[20],[22], [24].First of all the nature and sources of data namely primary data and secondary data. Primary data refers to the information collected by the researcher from sample respondents for the first time for the purpose of the study. Secondary data refers to the data already collected and readily available.

The sampling design refers to the population size, sample frame, sampling method and sample size. The sample size and accuracy of results are inversely related. However when the sampling method is scientific, even a smaller sample ensures accuracy and economy. Simple random sample is more reliable.

The quantitative studies provide more accurate results. For this purpose, the data collected are edited, tabulated and analysed with the help of statistical tools. Any study on humanities is not as accurate as research in physical sciences. So, limitations are given as a part of research design.

Both primary data and secondary data were used for the present study.

\section{Primary Data}

A pilot study was conducted among three big growers and equal number of small growers. After going through the response of planters, the questionnaire was suitably modified and finalized. The researcher contacted the farmer respondents in their own coffee estates and the dealer respondents in their godowns.

The questionnaries were administered and personal interviews were made with the respondents using structured questionnaire.

The questionnaire of farmers included questions concerning area, type of coffee, yield, various item of cost, marketing system, prices etc. The dealers were asked to give details of quantum of coffee purchased, sources, drying yard and goddown particulars, selling points, sources of finance etc[25],[27],[29].

\section{Secondary Data}

The secondary data on total area, yield, productivity etc in the district was collected from the office of the Joint Director of Horticulture and Coffee Board.

\section{Sampling Method} around 300 .

The universe or population size of coffee planters is

$10 \%$ of population is selected as samples for the study ie 30 .
Multi stage sampling technique was applied to select the respondents.

Stage I: In the Dindigul District there are five coffee zones namely such as Batalagundu, Pannaikadu, Perumalmalai, Adalur and Sirumalai.

Stage II : From each zone, two villages have been selected. Stage III: From each village, five planters have been selected randomly.

So $(5 \times 2 \times 5)$ ie 50 sample respondents are selected for our study.

The small growers ( $<10 \mathrm{ha})$ and big growers $(>10 \mathrm{ha})$ are selected in the ratio of $4: 1$ ie 40 small growers and 10 big growers.

Similarly from among coffee traders 10 dealer have been selected randomly.

\section{Statistical Tools Used}

Tabular and percentage analysis are used to interpret data relating to the socio-economic characteristics of the respondents.

Chi-square $\left(\mathrm{x}^{2}\right)$ test is used to test the relationship between cultivation of coffee and other crops by size of holdings.

$$
\chi_{c}^{2}=\sum \frac{\left(O_{i}-E_{i}\right)^{2}}{E_{i}}
$$

With $(\mathrm{C}-1)(\mathrm{R}-1)$ degrees of freedom

$\mathrm{O}=$ Observed frequency

$\mathrm{E}=$ Expected frequency

$\mathrm{C}=$ Number of column

$\mathrm{R}=$ Number of rows

Simple linear regression models are used to estimate the growth rate of coffee over time in the district.

$$
\mathrm{Y}=\mathrm{a}+\mathrm{bx}
$$

$\mathrm{Y}=$ Production , sales, price

$\mathrm{X}=$ Time factor

$a+b=$ Parameters to be estimated

The correlation co-efficient is used to find out the relationship between auction sales and weighted average price.

$$
r=\frac{n\left(\sum x y\right)-\left(\sum x\right)(\Sigma y)}{\sqrt{\left[n \sum x^{2}-\left(\sum x\right)^{2}\right]\left[n \Sigma y^{2}-\left(\sum y\right)^{2}\right]}}
$$

\section{LIMITATIONS}

Small planters normally do not maintain any records or accounts as regards expenditure and income. There is chance for memory bias also. Big planters, though keep records, are reluctant to reveal exact data. Therefore personal interviews are conducted to elicit authentic information with the support of statistical assistants and horticultural officers.

The survey was conducted among few selected farmers. So the generalization of results may not hold good for the entire plantation. 
The yield also is not uniform through out. Bumper crop in one year is followed by lean crop in the next year. So the study on average yield is another limitation. The scope of the present study is limited due to the paucity of time.

Table No - 1Number of Holding In States (2016-2017)

\begin{tabular}{|l|l|l|c|l|}
\hline S.No & Name of the Region & $<\mathbf{1 0 ~ h a}$ & $>\mathbf{1 0 h a}$ & Total \\
\hline 1. & Karnataka & 76960 & 2201 & 79161 \\
\hline 2. & Kerala & 77370 & 275 & 77645 \\
\hline 3. & Tamilnadu & 17656 & 350 & 18006 \\
\hline 4. & $\begin{array}{l}\text { Total for Traditional } \\
\text { Areas }\end{array}$ & 171936 & 2826 & 174762 \\
\hline 5. & $\begin{array}{l}\text { Non Traditional } \\
\text { (Andhra, Orissa) }\end{array}$ & 167370 & 26 & 167396 \\
\hline 6. & North Eastem Region & 10477 & 9 & 10486 \\
\hline & Grand Total & 349783 & 28614 & 358644 \\
\hline
\end{tabular}

Karnataka is the major coffee producing state in India accounting for 71.03 percent of India's total production. Kerala, TN and nontraditional areas account for 20.46, 6.68 and 1.83 percent respectively.

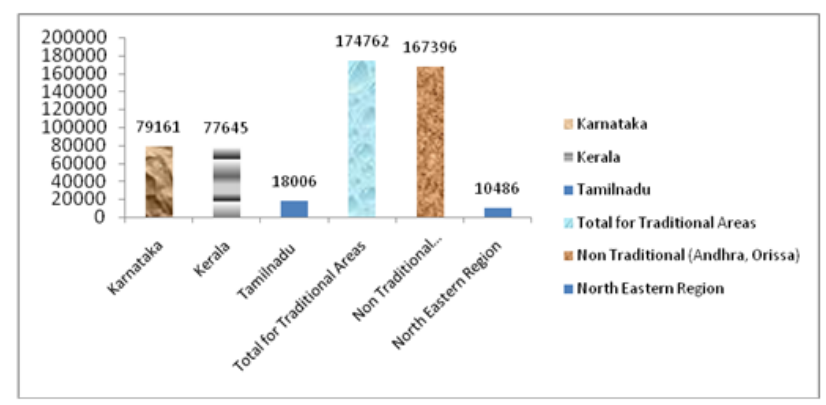

Figure - 1Number of Holding In States (2016-2017)

Table -2 Region wise distribution of holdings in TN

There are five coffee zones within the state TN. vizPulneys, Shevaroys, Nilgiris, Bodi hills and Anamalais. The region wise distribution of holdings is given below.

\begin{tabular}{|l|l|l|l|}
\hline Region & $<\mathbf{1 0}$ ha & $>\mathbf{1 0}$ ha & Total \\
\hline Pulneys & $6643(39 \%)$ & $136(38.8 \%)$ & $6779(39 \%)$ \\
\hline Shevaroys & $3756(22 \%)$ & $104(29.7 \%)$ & $3860(22.2 \%)$ \\
\hline Nilgiris & $5051(29 \%)$ & $49(14 \%)$ & $5100(29.3 \%)$ \\
\hline Bodi hills & $1556(9 \%)$ & $30(8.5 \%)$ & $1586(9.1 \%)$ \\
\hline Anamalais & 1 & $31(8.8 \%)$ & $32(0.1 \%)$ \\
\hline Total TN & $\begin{array}{l}|c| 350 \\
(2 \%)\end{array}$ & $\begin{array}{l}17357 \\
(100 \%)\end{array}$ \\
\hline
\end{tabular}

The Pulneys region tops among all the regions both under small plantations and large plantations followed by Nilgiris region. The Anamalai region is at the bottom.

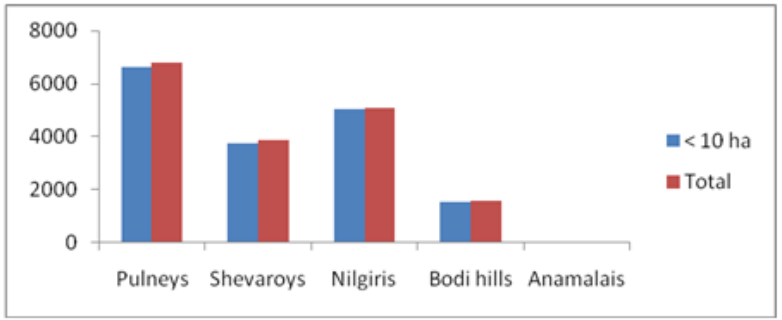

Table -2 Zone wise distribution of size of holdings in the district

There are five coffee zone in Dindigul district. The holding wise distribution of lands is presented below.

\begin{tabular}{|l|l|l|l|l|l|l|l|}
\hline \multirow{2}{*}{ S.No } & \multirow{2}{*}{ Zones } & \multicolumn{2}{|l|}{ Small Farm } & \multicolumn{2}{l|}{ Large Farm } & \multirow{2}{*}{ Total } \\
\cline { 3 - 7 } & & $\mathbf{0 - 2}$ & $\mathbf{2 - 4}$ & $\mathbf{4 - 1 0}$ & $\begin{array}{l}\mathbf{1 0 -} \\
\mathbf{2 5}\end{array}$ & $\begin{array}{l}\text { More than } \\
\mathbf{2 5}\end{array}$ & \\
\hline 1. & Batlagundu & 118 & 113 & 47 & 16 & $4-$ & 298 \\
\hline 2. & Pannaikadu & 1422 & 305 & 100 & 13 & - & 1840 \\
\hline 3. & Perumalmalai & 1446 & 262 & 42 & 3 & 2 & 1755 \\
\hline 4. & Adalur & 1400 & 215 & 163 & 55 & 23 & 1856 \\
\hline 5. & Sinumalai & 108 & 46 & 25 & 13 & 2 & 194 \\
\hline & Total & 4494 & 941 & 377 & 100 & 31 & 5943 \\
\hline
\end{tabular}

The small plantations are defined as those holdings up to 10 hectares and large ones with more than 10 hectares. As per this definition, $98 \%$ of the total holdings in the District belong to the category of small holdings. However the small holdings account for $72 \%$ of the total land area. In other world large holdings constituting $2 \%$ of holdings account for $28 \%$ of total land area. The same ratio is reflected in the case of all Zones vizBatlagundu, Pannaikadu, Perumalmalai, Adalur and Sirumalai.

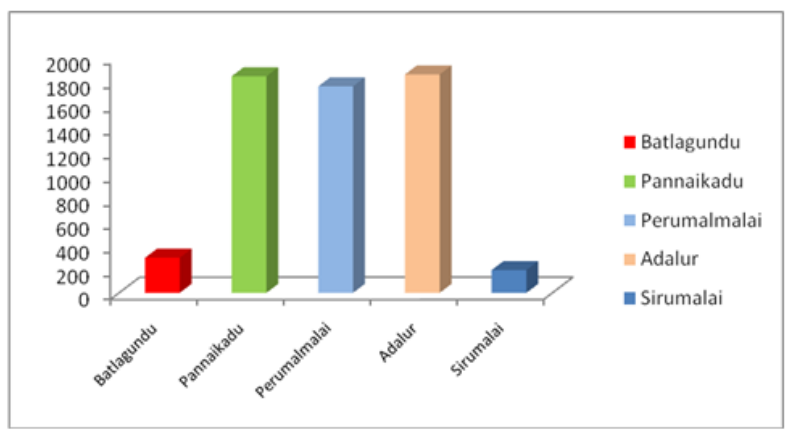

Table -3 Area, Production and Productivity in TN

The Tamilnadu state ranks third in area and production among the traditional coffee growing states. The area, production and productivity in Tamilnadu between 2006-07 and 2015-16 is given below 
Production and Marketing Of Coffee Crops With Special Reference To Coffee Plantations In Dindigul

\begin{tabular}{|l|l|l|l|}
\hline Year & $\begin{array}{l}\text { Area } \\
(\mathbf{H a})\end{array}$ & Production $\mathbf{M T}$ & $\begin{array}{l}\text { Productivity } \\
\mathbf{K g} / \mathbf{H a}\end{array}$ \\
\hline $2006-2007$ & 25108 & 13950 & 558 \\
\hline $2007-2008$ & 25108 & 14050 & 562 \\
\hline $2008-2009$ & 25108 & 12070 & 483 \\
\hline $2009-2010$ & 25108 & 12650 & 506 \\
\hline $2010-2011$ & 25708 & 13150 & 526 \\
\hline $2011-2012$ & 25540 & 13385 & 523 \\
\hline $2012-2013$ & 24461 & 12800 & 523 \\
\hline $2013-2014$ & 26835 & 13950 & 520 \\
\hline $2014-2015$ & 26835 & 13975 & 522 \\
\hline $2015-2016$ & 26835 & 14035 & 523 \\
\hline
\end{tabular}

The area is stagnant at 25108 ha during the two years from 2006-2007 to 2010- 2011. Similarly the area is constant at a higher level of 26835 ha from 2013 to 2016. The production level has been fluctuating, -falling from 2006-2007 to 2008-2009, recovering on 2010-2011 and 2011-2012, Slipped in 2012-2013 and improving in the last three years.

The peak rate in yield was seen on 2007-2008 with 562 Kgs per ha. Karl Pearson's correlation coefficient model has been used to find out the relationship been area and production.

The value of coefficient is found to be 0.532 . There is a positive and high relation between area under coffee and production of coffee. The result has also been found to be statistically significant.

The correlation co-efficient is 0.543 which means positive and high correlation between the area and production

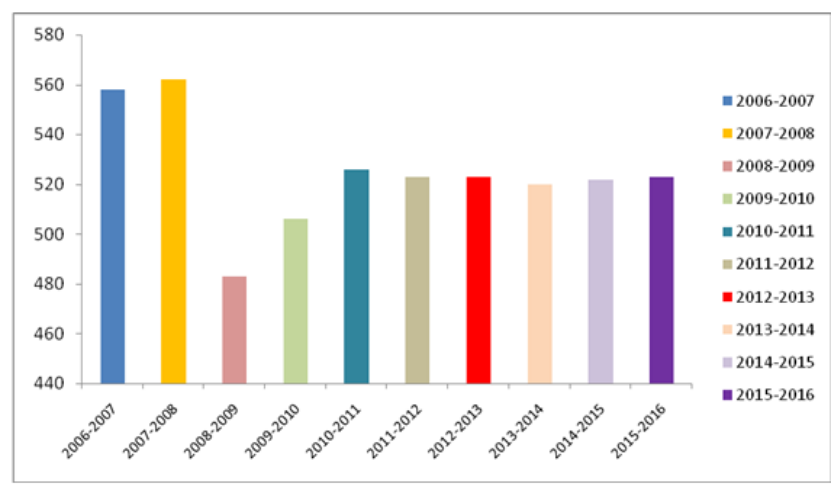

Figure - 3 Area, Production and Productivity in TN

Table - 4 Production and Productivity in Dindigul District.

\begin{tabular}{|l|l|l|}
\hline Year & $\begin{array}{l}\text { Production } \\
\text { M.T }\end{array}$ & $\begin{array}{l}\text { Productivity } \\
\text { Kg/ Ha }\end{array}$ \\
\hline $2008-2009$ & 3855 & 412 \\
\hline $2009-2010$ & 4800 & 454 \\
\hline $2010-2011$ & 3925 & 342 \\
\hline $2011-2012$ & 4445 & 457 \\
\hline $2012-2013$ & 4957 & 455 \\
\hline $2013-2014$ & 4882 & 458 \\
\hline $2014-2015$ & 5300 & 465 \\
\hline $2015-2016$ & 5130 & 514 \\
\hline $2016-2017$ & 5015 & 491 \\
\hline
\end{tabular}

The productivity of coffee in DindigulDt compared with that of Tamilnadu has been lesser in all years (vide previous table on T.N data)

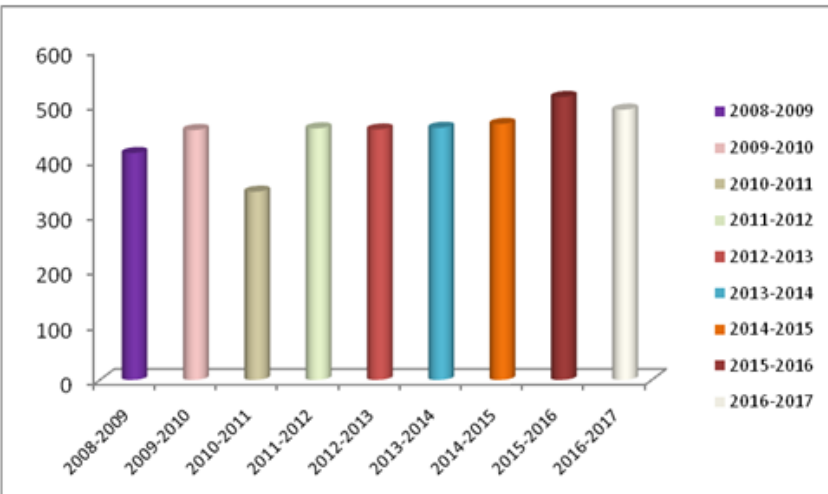

Figure -4 Production and Productivity in Dindigul District.

Table - 5 Zone Wise Production in The District

\begin{tabular}{|l|l|l|l|l|l|l|}
\hline Year & Bathagundu & Pannaikadu & Perumalmalai & Adalur & Sirumalai & Total \\
\hline $2008-2009$ & 800 & 1240 & 630 & 1185 & 200 & 3855 \\
\hline $2009-2010$ & 900 & 1600 & 700 & 1400 & 200 & 4800 \\
\hline $2010-2011$ & 440 & 1325 & 650 & 1350 & 170 & 3925 \\
\hline $2011-2012$ & 600 & 1550 & 605 & 1450 & 170 & 4445 \\
\hline $2012-2013$ & 775 & 1707 & 725 & 1445 & 305 & 4957 \\
\hline $2013-2014$ & 820 & 1650 & 725 & 1357 & 330 & 4882 \\
\hline $2014-2015$ & 850 & 1825 & 650 & 1575 & 400 & 5300 \\
\hline $2015-2016$ & 900 & 1570 & 640 & 1620 & 400 & 5130 \\
\hline $2016-2017$ & 870 & 1600 & 625 & 1490 & 430 & 5015 \\
\hline $\bar{x}$ & 772 & 1563 & 668 & 1430 & 289 & 4701 \\
\hline
\end{tabular}




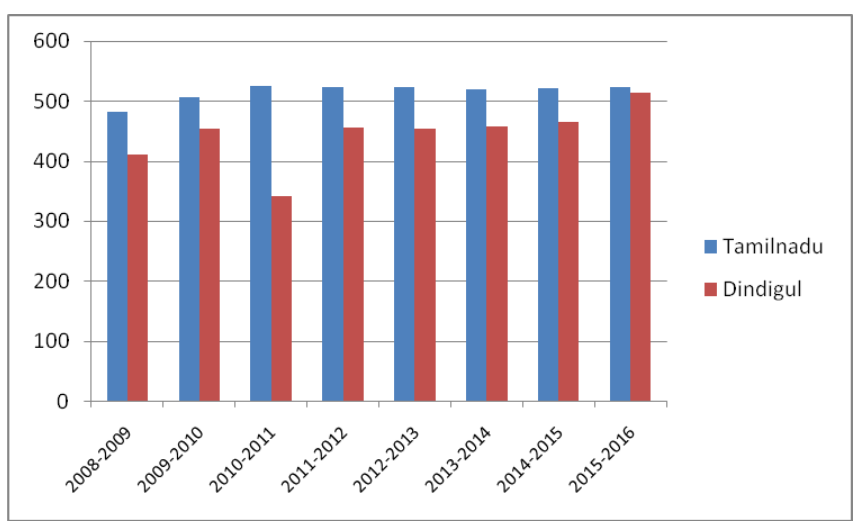

Figure - 5 Zone Wise Production in The District

\section{Trends is output (production)}

\section{Linear trend model}

The form of equation is $y=a+b t+U t$

In this model the researcher regress y on time $(\mathrm{t}) \mathrm{y}$ stands for coffee production.

If the slope coefficient is positive, there is upward trend of $y$. If it is negative, there is downward trend.

$\mathrm{R}^{2}$ factor refers to contribution of time factor to changes in production.

$\mathrm{t}$ value greater than 1.96 means the significance at 5\% level.

$x$ refers to arithmetic mean of production in the area over a period of time.

$\sigma$ (standard deviation) measures the variation of production i.e. lower the $\sigma$, more consistency, lesser variation.

\section{A. Linear Trend Model Result}

\begin{tabular}{|r|l|l|l|l|l|l|l|}
\hline $\begin{array}{l}\text { S. } \\
\text { No }\end{array}$ & Name of zone & a & b & t & R2 & Mean & $\begin{array}{l}\text { Standard } \\
\text { deviation }\end{array}$ \\
\hline 1. & Batlagundu & -3.31 & 0.007 & 1.119 & 15.2 & 772.78 & 154.66 \\
\hline 2. & Pannaikadu & -9.68 & $0.009 *$ & 2.087 & 38.3 & 1563 & 180.58 \\
\hline 3. & Perumalmalai & 13.165 & -0.012 & -0.469 & 3.1 & 668.89 & 39.19 \\
\hline 4. & Adalur & -18.876 & $0.017^{*}$ & 3.397 & 62.2 & 1430.22 & 129.424 \\
\hline 5. & Sinumalai & -1.835 & $0.024^{*}$ & 6.113 & 84.2 & 289.44 & 106.43 \\
\hline 6. & Dindigul district & -14.432 & $0.004^{*}$ & 3.291 & 60.7 & 4701 & 576.35 \\
\hline
\end{tabular}

* Significant at 5\% level.

$\mathrm{R}^{2}$ is highest in Sirumalai zone (84\%) followed by Adalur zone and District as a whole.

The trend values are statistically significant at Sirumalai, Adalur, the Dindigul district and Pannaikadu.

The coefficient of $b$ is high at Sirumalai, Adalur, Pannaikadu and Batlagundu. It is negative for Perumalmalai.

The trend i.e. production though positive is very moderate.

The second part of analysis of data is concerned with primary data. This is also divided into two segments.

The first segment covers the social economic characteristics of sample respondents viz coffee planters such as age, community, educational status, size of holding cropping pattern. Next part is dealing with production cost and marketing cost yield, Gross and Net returns, channels of distribution, constraints facing producers.
The second and final part deals with the dealers regarding the form of organization, product mix, extent of business, source of procurement and period of settlement.

\section{RESULTS AND DISCUSSIONS}

Age wise analysis shows the dominance of middle age group among sample respondents. Community wise analysis shows that majority of coffee planters belong to backward and most backward community.

The educational status of respondents shows that half of the respondents have completed school education and one third of the planters are graduates.

\section{A. Size of holding}

The size of holding in the study area also reflects the holding distribution of not only the district (Dindigul) the State (Tamilnadu) and even all other coffee producing states i.e. 80 percent of the sample respondents belong to the category of small planters i.e. below 10 hectares. Even among item marginal farmers constitute one fourth and those who own 2-4 ha more than one third.

\section{B.Cropping pattern}

The cropping pattern shows the preference for mixed crops. Though coffee is the primary crop, the other subsidiary crops are pepper, hill banana, orange and avacoda. No la2rge planter produces exclusive coffee. Among the small planters, 90 percent follow mixed crop pattern. The mixed crop pattern helps the planters to supplement their main source of income and better utilization of overheads.

\section{C.Cost of production}

The broad classification of production cost is into fixed cost and variable cost.

Fixed cost which is constant irrespective of level of output constitutes $14 \%$ and $17 \%$ for small and large planters respectively. So the major component of total cost is variable cost which is $86 \%$ and $83 \%$ for small and large growers.

The variable cost also known as direct cost comprises material cost and labour cost. The labour cost constitutes a bigger share of variable cost, almost double the material cost. The three main items of material cost are on manures, fertilizers and pesticides. Among them fertilizer cost is predominant constituting more than two third of total material cost. Manures are the organic component of materials. Manures are either purchased from outside or got from animals (cows and goats) owned by the planters. In case of manures from own animals, the value of dug is imputed. There is close relationship between the doses of manures and fertilizers on the one hand and yield of coffee on the other.

The labour cost is the largest of all costs. The two major items of cost on labour are the harvesting (picking of charries) and land preparation.

\section{D.Yield and returns}

The yield of coffee depends on the age of the plant, application of fertilizers, variety of coffee seeds, monsoon quantum 
and timing. The yield is not uniform throughout. If there is bumper harvest in one year, there will be lean crop in the subsequent year. So, the average yield is taken into calculation. The yield rate per hectare is $460 \mathrm{~kg}$ over all, $465 \mathrm{~kg}$ for small growers and $455 \mathrm{~kg}$ for large cultivators.

The market price of coffee parchment is highly volatile. The commission agents quote prices on the basis of coffee markets in US and UK. So the average price prevailing during the season is considered. In the present study the price presumed is Rs.130 per $\mathrm{kg}$ of parchment. The price mentioned here stands for fair average quality. The bits and blacks are paid half this price.

The gross returns per hectare are Rs.59800 overall, Rs.60350 for small growers and Rs.59150 for large planters. The net returns arrived after subtracting annual costs from gross returns in Rs.26650 for small Rs. 25750 for big growers and Rs. 25200 overall.

After adjusting towards marketing costs incurred by cultivators the net income is still lower.

\section{E.Channels}

The two main channels of distribution are widely prevalent in the study area.

Channel I Producer $\rightarrow$ Commission agents $\rightarrow$ curing agents Channel II Producer $\rightarrow$ Curing agents

\section{F. Marketing cost}

In channel I, commission charge and transport cost are high.

In channel II transport and labour cost are high.

The processing expenses are the major item chargeable by curing agents.

\section{G.Problems}

Regarding the constraints confronting the coffee cultivation labour scarcity is cited by $94 \%$, monsoon failure by $90 \%$ and pest attack by $82 \%$.

Unsteady and unremunerative price is expressed by $96 \%$ respondents as a marketing related problem.

\section{E.Findings on dealers}

Majority of dealers undertake their coffee business as a partnership form of organization. Larger proportion of dealers (60 percent) deal in other plantation products like pepper and cardamom (70\%) along with coffee. Majority of dealers do the coffee business as a part time business. Dealing in coffee trading is a full time profession for just $30 \%$ of dealers.

Majority of the dealers $(60 \%)$ procure directly from the coffee growers. Auction centres and licensed traders are resorted by very few dealers.
Cash payment is made by $30 \%$ of dealers immediately on delivery of goods. Another $30 \%$ of dealers take a maximum of 15 days for settlement.

\section{F. Policy implications}

The discussions in the previous chapter are summarized in this part with the view to drawing specific conclusion.

1. As per the analysis on trends in growth rate, the increase in production is because of extensive cultivation i.e. addition to area rather than intensive cultivation. So, the horticultural department and the Coffee Board have to take necessary steps to increase production per hectare i.e. productivity.

2. The establishment cost during the gestation period is rather huge and the planters have to wait for atleast five years to see the first harvest and atleast 10 years to break even. So the Government should provide interest free loan and even subsidy to meet the establishment cost[31],[33].

3. As there is acute labour scarcity, new labour saving devices in farm operations can be introduced by the agricultural universities and such equipments are to be provided to planters especially small growers at subsidized price.

4. Next to monsoon, the prices of coffee beans are found to be capricious and unremunerative. Therefore the cost based statutory minimum support prices are to be implemented to make the coffee plantation viable and profitable.

\section{VI.CONCLUSION}

The present study on production and marketing of coffee provides valid conclusion for policy makers. Production is fluctuating due to vagaries of monsoon. The rise and fall in production keep the overall growth stagnant. The productivity is low[26],[28],[30]. Labour scarcity poses a big challenge to the production operations. Institutional support is the need of the hour for providing inputs at reasonable rate and ensuring marketing support through remunerative price.

\section{REFERENCES}

1) BharthVajan R., Ramachandran S.,Psychographic dimensions of training,2016,International Journal of Pharmacy and Technology,V-8,I-4,P-23727-23729

2) Balakrishnan P., Bharthvajan R.,A study on human resource planning in hospitals in Chennai City,2014,International Journal of Applied Engineering Research,V-9,I-22,P-7503-7507

3) Priyadarsini P., Bharthvajan R.,Role of emotional intelligence training programme in reducing the stress of the nurses,2014,International Journal of Applied Engineering Research,V-9,I-22,P-7411-7421

4) Kerinab Beenu G., Bharthvajan R.,Empirical analysis on the cosmetic buying behavior of young women in South India,2014,International Journal of Applied Engineering Research,V-9,I-22,P-7361-7366

5) Balakrishnan P., Bharthvajan R.,Whistling in the wind,2014,International Journal of Applied Engineering Research,V-9,I-22,P-7586-7593

6) Krishnan B., Peter M.,Health hazards of Indian Bpo employee-an alarming issue,2014,International Journal of Applied Engineering Research,V-9,I-22,P-7336-7341

7) Kerinab Beenu G.H., Peter M.,Role of insurance in economic development,2014,International Journal of Applied Engineering Research,V-9,I-22,P-7532-7539

8) Balakrishnan P., Peter M., Priyadarsini P.,Efficiency of safety measures for wellbeing of employees in manufacturing

industry,2014,International Journal of Applied Engineering Research,V-9,I-22,P-7376-7382 
9) Anbarasi M., Praveen Kumar S.,Online sales promotions of herbal products and its effectiveness towards tanisha.com,2019,Indian Journal of Public Health Research and Development,V-10,I-1,P-195-200

10) Anbarasi M., Praveen Kumar S.,Various online marketing and promotions strategies to improve the validation towards the organic products in the pharmaceutical sectors,2019,Indian Journal of Public Health Research and Development, V-10,I-1,P-263-269

11) Loganathan R., Praveen Kumar S.,Grievance handling a key factor for solving issues of employees in an organization,2014,International Journal of Applied Engineering Research,V-9,I-22,P-7483-7491

12) Loganathan R., Praveen Kumar S.,Study on preference of private label brands in super and Hypermarkets,2014,International Journal of Applied Engineering Research,V-9,I-22,P-7327-7335

13) Smitha M., Praveen Kumar S.,Understanding stress and its managementamong the nurses in Chennai city,2014,International Journal of Applied Engineering Research,V-9,I-22,P-7560-7565

14) Kerinab Beenu G.H., Praveen Kumar S.,A study on the investment behavior of Chennai investors in mutual fund schemes,2014,International Journal of Applied Engineering Research,V-9,I-22,P-7520-7525

15) Loganathan R., Praveen Kumar S.,Retention strategies key for organizational productivity,2014,International Journal of Applied Engineering Research,V-9,I-22,P-7443-7447

16) Pavithra J., Ganesan M., Brindha G.,State wise analysis of microfinance sector in India,2016,International Journal of Pharmacy and Technology,V-8,I-4,P-23417-23432

17) Pavithra J., Ganesan M.,A comparative study on microfinance in India and abroad,2016,International Journal of Applied Business and Economic Research,V-14,I-8,P-5471-5476

18) Pavithra J., Ganesan M.,A study on awareness and impact of micro-financial schemes,2016,International Journal of Applied Business and Economic Research,V-14,I-8,P-5449-5460

19) Senthilmurugan P., Pavithra J.,Consumer preference towards organised retailing with reference to Big Bazaar,2014,International Journal of Applied Engineering Research,V-9,I-22,P-7469-7475

20) Senthilmurugan P., Pavithra J.,Implication of social media marketing in growing healthcare industry,2014,International Journal of Applied Engineering Research,V-9,I-22,P-7448-7456

21) Loganathan R., Pavithra J.,Consumer perception towards private label brand over other brands in super markets and hypermarkets,2014,International Journal of Applied Engineering Research,V-9,I-22,P-7355-7360

22) Kerinab Beenu G., Pavithra J.,Tradeâ€"off between liquidity and profitability in logistics industry,2014,International Journal of Applied Engineering Research,V-9,I-22,P-7398-7401

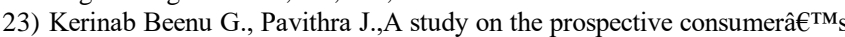
perception towards utility cars in Chennai city,2014,International Journal of Applied Engineering Research,V-9,I-22,P-7526-7531

24) Pavithra J., Dilli Babu P., Ambuli T.V.,A study on budgetary control at Maruti Service Masters, Chennai,2014,International Journal of Applied Business and Economic Research,V-12,I-2,P-151-161

25) Pavithra J., Dilli Babu P., Ambuli T.V.,A study on customer satisfaction of retro Garments Pvt Ltd, Chennai,2014,International Journal of Applied Business and Economic Research,V-12,I-2,P-381-391

26) Kerinab Beenu G.H., Pavithra J., Senthilmurugan P.,A study on the influence of promotional activities for TATA ARIA among consumers in Chennai,2014,International Journal of Applied Engineering Research,V-9,I-22,P-7572-7578

27) Vijayaragavan S.P.,An investigative expert that's general FBG sensors,International Journal of Mechanical Engineering and Technology,V-8,I-8,PP-1500-1505,Y-2017

28) Vijayaragavan S.P.,Equalization routing protocol for Wi-Fi sensor strategy,International Journal of Mechanical Engineering and Technology,V-8,I-8,PP-1662-1666,Y-2017

29) Karthik B., Kiran Kumar T.V.U., Vijayaragavan P., Bharath Kumaran E.,Design of a digital PLL using 0.35 $\hat{\mathrm{I}}^{1 / 4 \mathrm{~m}}$ CMOS technology, Middle East Journal of Scientific Research,V-18,I-12,PP-1803-1806,Y-2013

30) Kanniga E., Selvaramarathnam K., Sundararajan M.,Kandigital bike operating system,Middle - East Journal of Scientific Research,V

31) Jasmin M., Vigneshwaran T., Beulah Hemalatha S.,Design of power aware on chip embedded memory based FSM encoding in FPGA,International Journal of Applied Engineering Research,V-10,I-2,PP-4487-4496,Y-2015

32) Jasmin M.,Optimization techniques for low power VLSI circuits,Middle East Journal of Scientific Research,V-20,I-9,PP-1082-1087,Y-2014

33) Jasmin M., Vigneswaran T.,Fuzzy controller for error control of on - Chip communication,2017 International Conference on Algorithms, Methodology, Models and Applications in Emerging Technologies, ICAMMAET 2017,V-2017-January,I-,PP-1-5,Y-2017

\section{AUTHORS PROFILE}

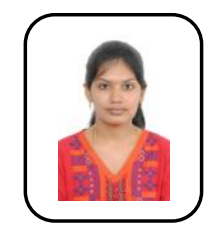

M. Anbarasi Research Scholar, Department of MBA, Bharath Institute of Higher Education and Research, Chennai, India.

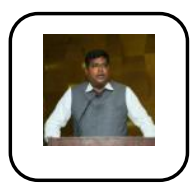

Dr. S. Praveen Kumar Professor, Department of MBA, Bharath Institute of Higher Education and Research, Chennai, India. 